of the recently published work "Naven" (see NaturE of March 13, p. 454) in which he gives an account of some of his observations among the Iatmul tribes in an expedition to the Sepik River, New Guinea, in 1933, and elaborates an extension of the 'functional' method in sociological investigation.

\section{Iron and Steel Institute: Bessemer Gold Medals}

The Bessemer Gold Medals for 1937 of the Iron and Steel Institute have been awarded to Colonel N. T. Belaiew and Aloyse Meyer. Colonel Belaiew of Paris, a former pupil of Prof. Tschernoff of the Military Academy, Petrograd, has, during the last twenty-five years, published a number of papers of outstanding importance on metallurgy. These have dealt mainly with the crystallization of metals, and in particular steel. His studies of the constitution and solid geometry of pearlite, sorbite and troostite demonstrated the true width of the lamellæ in these structures and the relation between the angle of section and the apparent width. His suggestion of a definite unit of crystal size of iron has been confirmed from other sources. He also studied the primary and secondary crystallization in steel and the origin of the 'Widmanstätten' structure in steel and meteorites. His insight is strikingly shown by his insistence on 'granulation' in the austenitic zone, the explanation of which has been provided by the subsequent discovery of the delta-gamma change in iron at very high temperatures. He has studied the manufacture and uses of Damascene steel and related the results to the manufacture of high-class steels at the present time, in particular high-speed steel.

M. Aloyse Meyen, of Luxemburg, is an honorary vice-president of the Institute, and is well known as head of the Société Anonyme ARBED, the great Luxemburg combine and the second largest iron and steel company in Europe. He has rendered unique services to the iron and steel industry as president, since 1928, of the Entente Internationale de l'Acier. In addition, his encouragement of the acquisition and diffusion of technical information and metallurgical knowledge in the Luxemburg-Lorraine district has been invaluable to the progress of the industry; he was actively connected with the introduction of the Thomas-Gilchrist process of steel manufacture into the district-the Hauts Fourneaux et Acieries de Dudelange was one of the first works in Europe and the first in the Luxemburg-Lorraine district to adopt this method, which revolutionized the manufacture of steel on the Continent. Since the Great War, he has been responsible for the introduction of modern American blast-furnace practice in the works under his control.

\section{Richard Anthony Proctor (I837-I888)}

IN the mid-Victorian era there were no more popular books on astronomy than those of Richard Anthony Proctor, the centenary of whose birth falls on March 23. Possessing a remarkable power of lucid exposition and almost unbounded energy, in his comparatively short life he published about sixty separate works, wrote numerous memoirs and delivered many lectures in Great Britain, the United States and Australia. He was, however, no mere exponent, and in the little leisure he enjoyed he studied the planet Mars, plotted on a single chart the 324,198 stars of Argelander's "Durchmusterung" and made the important discovery of 'star-drift'. Proctor was the son of a London solicitor and was born in Cheyne Row, Chelsea. His father died in 1850 and left the family ill-provided for ; so Proctor became a clerk in the London and Joint Stock Bank, but was able after a year or two to study at the University of London; at the age of nineteen years he entered St. John's College, Cambridge, graduating as 23rd Wrangler in 1860. He then read for the law, but this was soon abandoned for science, and in 1865 he published his first book, "Saturn and its System".

Proctor married before leaving Cambridge and for a time was in pecuniary difficulties. In 1868 he scored his first financial success with his "Half Hours with the Telescope". This was followed by his "Other Worlds than Ours". It was about the time this appeared that after working five years without a holiday he wrote, "I would willingly have turned to stone-breaking or any other form of hard and honest but unscientific labour if a modest competence in any such direction had been offered me." For a short time he taught mathematics in a school at Woolwich. He was elected a fellow of the Royal Astronomical Society in 1866; in 1872 he became honorary secretary to the Society, but this he resigned in order to undertake a lecture tour in America. The tour was a success and in 1879 , after the death of his wife, he made a tour to Australia. In 1881 he founded the periodical Knowledge, and then returned to the United States, marrying a widow, Mrs. Crawley, and settling at St. Joseph, Missouri. A few years later he transferred his house and observatory to Florida. In September 1888 he was about to sail from New York on a visit to England but was attacked by fever and died in hospital on September 12, at the age of fifty-one years.

\section{Printing and Allied Trades Research Laboratories}

THe new Laboratories of the Printing and Allied Trades Research Association were officially opened by H.R.H. the Duke of Gloucester on March 9 in the presence of the Advisory Council of the Department of Scientific and Industrial Research and the Council and members of the Research Association. The laboratories are situated just off Fleet Street in the centre of London's printing district, and comprise about seven thousand square feet devoted to chemical and physical laboratories, library and offices for the investigation of the major and the day-to-day problems of the printing, newspaper, ink and paper industries. The basement has been converted into an optics laboratory for colour measurement in connexion with colour printing and the measurement of the opacity of paper, etc. A strong-room in the basement has been converted into a constant humidity laboratory where the temperature and relative humidity are maintained at $65^{\circ} \mathrm{F}$. and 65 per cent. 